\title{
APAKAH SHELTER BUS BATIK SOLO TRANS AKSESIBEL BAGI PENYANDANG DISABILITAS?
}

\author{
Endang Sri Wahyuni \\ Poltekkes Kemenkes Surakarta JurusanOkupasi Terapi
}

\begin{abstract}
Background: Availability of facilities and infrastructure for public facilities that facilitate accessibility for people with disabilities is very important. The basic thing for increasing the independence of people with disabilities is the availability of adequate public service facilities. One of the supporting facilities to fulfill public facilities is the Batik Solo Trans bus shelter. The purpose of this study is to analyze the accessibility of people with disabilities in assessing the assistance of Trans Solo Batik buses in Surakarta City. Method: This type of research is explorative qualitative research. Methods of interviewing, observation, and documentation. Data is obtained through interviews with persons with physical and mental disabilities. The data analysis technique uses the triangulation method. Results: Persons with disabilities are still experiencing difficulties in accessing due to architectural barriers. Design shelter still does not meet established accessibility standards. Conclusion: Shelter Solo Trans Batik buses in Surakarta City are not accessible for people with disabilities. The limited accessibility for people with disabilities requires further study in a design that is in accordance with the principles of ergonomics and accessibility in order to accommodate the public interest in general and people with disabilities in particular.
\end{abstract}

Keywords: accessibility, disability, disabled, public services, shelter

\section{PENDAHULUAN}

Menurut The International Classification of Functioning, Disability and Health/ICF menyatakan bahwa difabel/disabilitas merujuk pada kondisi seseorang yang mengalami kesulitan pada area fungsionalnya yang dipandang secara holistik dan terjadi karena adanya hubungan interaksi antara faktor personal, kontekstual, dan lingkungan (Hemmingsson and Jonsson, 2005). Kemandirian kaum difabel dalam menjalankan aktivitas kehidupan seharihari tidak terlepas dari tersedianya sarana dan prasarana fasilitas publik yang memenuhi kaidah aksesibilitas seperti adanya modifikasi lingkungan (Hurst, 2003; Imrie, 2004; Ueda and Okawa,
2003). Masalah mendasar bagi kaum difabel adalah kesulitan dalam mengakses layanan publik terutama pada bidang transportasi umum (Dwiyanto, 2008). Hal tersebut tidak terlepas dari adanya hambatan arsitektural yang ada sehingga sulit diakses oleh kaum difabel yang mengakibatkan mereka kehilangan hak dalam memperoleh pelayanan yang setara dengan warga negara lainnya (Tarsidi, 2008).

Berdasarkan data Dinas Kependudukan dan Pencatatan Sipil Kota Surakarta (2012), jumlah penyandang difabel di Kota Surakarta mencapai 1.237 orang yang terdiri dari 354 penyandang cacat fisik, 111 netra/buta, 193 cacat rungu/wicara, 311 cacat mental/jiwa, 70 
cacat fisik dan mental, serta 198 cacat lainnya.

Sebenarnya pemerintah pun telah memberikan perlindungan dan hak yang sama bagi kaum difabel yang diimplementasikan dalam UU No 4 Tahun 1997 tentang kemudahan dalam aksesibilitas bagi kaum difabel serta UU No 25 Tahun 2009 yang mengatur dengan tegas tentang azas kemudahan aksesibilitas pada pelayanan publik bagi kaum difabel (Lembaga Negara RI, 2009). Hal tersebut didukung dengan Permen PU No. 30/PRT/M/2006 tentang Pedoman Teknis Fasilitas dan Aksesibilitas pada Bangunan dan Lingkungan, KepMen Perhubungan RI No. KM. 71 tahun 1998 tentang aksesibilitas bagi penyandang cacat dan orang sakit pada sarana dan prasarana perhubungan. Pemerintah kota Surakarta pun telah memiliki Perda Kota Surakarta No.2 Tahun 2008 yang mengatur tentang kesetaraan warga difabel, akan tetapi kenyataannya ketersediaan sarana dan prasarana ramah difabel masih jauh dari yang diharapkan sesuai dengan amanat perundang-undangan yang ada.

Dari paparan tersebut, maka penelitian ini sangat penting dilakukan guna menganalisis lebih lanjut mengenai aksesibilitas shelter Batik Solo Trans bagi pemenuhan hak penyandang disabilitas pada bidang transportasi umum di Kota Surakarta. Fokus kajian aksesibilitas dilihat dari perspektif pengguna layanan (user).

\section{METODE PENELITIAN}

Penelitian ini merupakan
penelitian kualitatif eksploratif
menggunakan strategi pendekatan studi
kasus. Kasus penelitian ini adalah kondisi
pelayanan publikyang terkait dengan

aksesibilitas dan hambatan kaum difabel dalam mengaksesshelter bus Batik Solo Trans.Teknik pengumpulan data berupa wawancara mendalam, observasi dan studi dokumen. Keabsahan data peneliti menggunakan triangulasi sumber data, metode dan teori. Informan penelitian ini adalah user atau pengguna jasa transportasi umum berupa bus Batik Solo Trans yangterdiri dari kaum difabel dengan cacat fisik, rungu/wicara, netra, dan mental) di Kota Surakarta.

\section{HASIL PENELITIAN}

Karakteristik informan penelitian terdiri dari kaum difabel pengguna bus Solo Batik Trans dengan cacat fisik 3 orang, 2 rungu, 3 wicara, 3 netra, dan 2 mental. Usia informan sekitar 19-50 tahun dengan jenis kelamin laki-laki dan perempuan.

Berdasarkan hasil deep interview terhadap informan, maka didapatkan hasil bahwa: ukuran pintu dari jalur lambat/trotoar menuju shelter bus sempit dan curam sehingga menyulitkan untuk kursi roda mengaksesnya, bahkan ada yang sama sekali tidak bisa diakses karena tidak dilengkapi dengan ram yang memadahi; material penyusun lantai shelter terbuat dari bahan keramik yang licin jika terkena air hujan dan berpotensi menyebabkan jatuh; ukuran ram yang tersedia sempit dan curam; ruang shelter belum memenuhi kaidah ukuran yang dianjurkan sehingga kurang luas, serta adanya keterbatasan rambu penanda dalam shelter seperti running text dan alarm.

\section{PEMBAHASAN}

\section{Difabel fisik}

Difabel fisik dengan kursi roda mengalami hambatan karena adanya 
desain shelter yang belum memenuhi kaidah aksesibilitas sehingga kurang aman bahkan tidak dapat diakses. Tarsidi (2008) menyatakan bahwa pengguna kursi roda banyak mengalami hambatan dalam mobilitas karena adanya keterbatasan desin arsitektural. Public Disclosure Authorized (2013) memperkuat bahwa shelter dibuat cukup luas agar dapat memberi ruang gerak bagi kursi roda dan pengguna alat bantu jalan.

2. Difabel rungu/wicara

Hambatan fasilitas berupa adanya rambu petunjuk elektronik menjadi permasalahan bagi kaum difabel rungu/wicara. Hal ini didukung oleh pemaparan Ariyani (2010) yang menyatakan bahwa pemberian informasi pada difabel rungu dapat diberikan melalui indera visual berupa running text, bel peringatan kebakaran, lampu yang berkedip-kedip, serta gestur bahasa isyarat.

3. Difabel netra

Difabel netra terhambat karena keterbatasan design bangunan dan fasilitas penunjuk berupa audio dan taktil. Sejalan dengan Public Disclosure Authorized (2013) yang menyatakan bahwa untuk membantu seseorang yang mengalami gangguan visual, dapat difasilitasi dengan pelayanan informasi taktil seperti braille atau tactile sign maupun audible information di tempat pemberhentian bus/terminal. Bagi yang menderita low vision dapat menggunakan informasi visual statik (tanda, stiker, dan poster) berukuran besar dan dapat terbaca dari kejauhan.

4. Difabel mental

Bagi difabel mental tidak mengalami hambatan karena bisa bertanya, meniru, bahkan mencontoh perilaku orang lain saat mengalami kesulitan. Menurut Aryani (2010), faktor keselamatan merupakan hal utama bagi difabel mental sehinggi membutuhkan bangunan bersudut tumpul.

\section{KESIMPULAN DAN SARAN}

Bangunan shelter belum memenuhi persyaratan teknis fasilitas dan aksesibilitas bangunan dan lingkungan seperti ukuran dasar ruang, pintu, ram, tangga, rambu, dan marka sesuai PERMEN PU No.30/PRT/M 2006. Shelter tidak asesibel untuk kaum difabel.

Saran yang dapat diberikan adalah: adanya sistem pembangunan yang berpedoman pada safety city terutama bagi kaum difabel, melibatkan public bisnis untuk mewujudkan pembangunan pelayanan publik yang ramah dan aman bagi kaum difabel, adanya perencanaan kebijakan dan keputusan dalam pembangunan aksesibilitas lingkungan, serta melibatkan segala sektor masyarakat dan stekholder dalam pembangunan fasilitas publik.

\section{DAFTAR RUJUKAN}

Aryani, D dan Rosinta, F. 2010. Pengaruh Kualitas Layanan terhadap Kepuasan Pelanggan dalam Membentuk Loyalitas Pelanggan. Jurnal Ilmu Administrasi dan Organisasi. Vol.17. No.2.

Dispendukcapil. 2012. Komposisi

Penduduk Menurut Karakteristik Sosial. http://dispendukcapil.surakarta.go. $\mathrm{id} / 20 X I V / i n d e x . p h p / i d / 2014-05-$ 21-04-43-06/2014-05-21-04-4355/kualitas-penduduk/item/33- 
komposisipendudukmenurutkarakt eristiksosial Diakses 22 April 2014. 15.27 WIB

Dwiyanto, A. 2008. Reformasi Birokrasi Publik di Indonesia. Yogyakarta: Gadjah Mada University Press.

Hemmingsson, H., \& Jonsson, H. 2005. An Occupational Perspective on the Concept of Participation in the International Classification of Functioning, Disability and Health--Some Critical Remarks. American Journal of Occupational Therapy, 59(5), 569-576.

Hurst, R. 2003. The International Disability Rights Movement and The ICF. Disability and Rehabilitation, 25(11-12), 572576.

Imrie, R. 2004. Demystifying Disability: A Review of The International Classification of Functioning, Disability and Health. Sociology of Health \& Illness, 26(3), 287305.

Lembaga Negara RI. 1997. UU No 4 Tahun 1997 tentang penyandang cacat

Lembaga Negara RI. 2009. UU No 25 Tahun 2009 tentang pelayanan publik
Menteri Pekerjaan Umum. 2006. Keputusan Menteri Pekerjaan Umum No 30/PRT/M/2006 tentang Pedoman Teknis Fasilitas dan Aksesibilitas pada Bangunan Gedung dan Lingkungan

Menteri Perhubungan. 1998. Keputusan Menteri Perhubungan No KM 71 Tahun 1998 tentang Aksesibilitas Penyandang Cacat dan Orang Sakit pada Sarana dan Prasarana Perhubungan

Pemerintah Kota Surakarta. 2008. Perda Kota Surakarta No 2 Tahun 2008 tentang Kesetaraan Warga Difabel

Public Disclosure Authorized. 2013. Improving Accessibility to Transport for People with Limited Mobility (PLM). A Practical Guidance Note. Middle East and North Africa Region: Sustainable Development Department

Tarsidi, D. 2008. Peranan Orang Tua dalam Perkembangan Kompetensi Sosial Anak. Universitas Pendidikan Indonesia (UPI)

Ueda, S., \& Okawa, Y. (2003). The subjective dimension of functioning and disability: What is it and what is it for? Disability and Rehabilitation, 25(11-12), 596-6 